\title{
Performance of Dairy Calves Fed Diet Containing Ca-Palm Oil Fatty Acid and Sapindus rarak Fruit
}

\author{
Wina E, Widiawati Y, Tangendjaja B \\ Indonesian Research Institute for Animal Production, P.O. Box 221 Bogor 16002 Indonesia \\ E-mail:ewina2013@gmail.com
}

(received 23-05-2018; revised 22-06-2018; accepted 26-06-2018)

\begin{abstract}
ABSTRAK
Wina E, Widiawati Y, Tangendjaja B. Performans sapi perah anak yang diberi pakan mengandung kalsium-asam lemak sawit dan buah Sapindus rarak. JITV 23(2): 71-76. DOI: http://dx.doi.org/10.14334/jitv.v23i2.1828

Garam kalsium-asam lemak sawit (CaFA) diberikan kepada induk sapi perah terutama saat periode awal laktasi sebagai sumber energi yang padat untuk meningkatkan produksi susu. Buah lerak (Sapindus rarak, SrF) mengandung kadar saponin tinggi dan dilaporkan dapat meningkatkan berat badan domba, produksi susu dan menekan populasi protozoa di dalam rumen. Percobaan ini menggunakan kombinasi CaFA dan SrF untuk meningkatkan performans anak sapi perah. Tiga puluh dua ekor anak sapi FH digunakan dalam percobaan dalam rancangan blok pola faktorial (2x2). Faktor pertama adalah CaFA (tanpa dan dengan 2,5\% CaFA), dan faktor kedua adalah $\mathrm{SrF}$ (tanpa dan dengan 0,3\% $\mathrm{SrF}$ dalam pakan). Jenis kelamin ternak diperlakukan sebagai blok. Pakan disusun sebagai pakan komplit mengandung protein kasar 17\% dan TDN min 69\%, Net energi untuk pemeliharaan $1.70 \mathrm{Mcal} / \mathrm{kg}$ and Net energi untuk pertambahan bobot badan $1.03 \mathrm{Mcal} / \mathrm{kg}$. Pakan diberikan sebanyak $3 \%$ dari berat badan ternak selama 14 minggu termasuk 2 minggu masa adaptasi. Pengumpulan feses untuk mengukur kecernaan pakan dilakukan pada akhir percobaan. Tidak ada pengaruh yang nyata pada interaksi antar kedua faktor untuk semua pengukuran. Pertambahan bobot badan harian yang menerima SrF lebih tinggi dibandingkan tanpa diberikan SrF (896,9 dibanding 853,7 g/hari) sedangkan yang diberi CaFA lebih rendah dari pada tanpa diberi CaFA (860,6 dibanding $890 \mathrm{~g} / \mathrm{hari})$ tetapi pengaruh keduanya ( $\mathrm{SrF}$ dan $\mathrm{CaFA}$ ) tidak signifikan $(\mathrm{P}>0,05)$. Konsumsi $\mathrm{BK}$ cenderung lebih tinggi pada yang diberi $\mathrm{SrF}(4.4$ dibandingkan 4,3 kg/hari). Nilai kecernaan BK tidak berbeda diantara perlakuan. Disimpulkan bahwa pemberian tepung buah Sapindus rarak pada level 0,3\% tidak nyata meningkatkan pertambahan bobot badan harian tetapi dapat mengurangi kasus diare pada anak sapi. Kalsium asam lemak dapat digunakan sebagai sumber energi terlindungi pada level 2,5\% tanpa pengaruh negatif terhadap performans anak sapi.
\end{abstract}

Kata Kunci: Kalsium Asam Lemak Sawit, Sapindus rarak, Saponin, Anak Sapi

\begin{abstract}
Wina E, Widiawati Y, Tangendjaja B. Performance of dairy calves fed diet containing Ca-palm oil fatty acid and Sapindus rarak fruit. JITV 23(2): 71-76. DOI: http://dx.doi.org/10.14334/jitv.v23i2.1828

Calcium salts of palm oil fatty acid (Ca-FA) is a high dense energy source that is protected from degradation in the rumen. Sapindus rarak fruits $(\mathrm{SrF})$ contain high level of saponin and have been reported to increase body weight sheep or cattle and reduced protozoa population in the rumen. This experiment used a combination of Ca-FA and SrF to improve the performance of weaned dairy calves. Thirty two heads of calves of Indonesian Holstein were used in factorial block design experiment $(2 \times 2)$. The first factor was Ca-FA (with $2.5 \%$ and without addition of Ca-FA) while the second factor was $\mathrm{SrF}$ (with $0.3 \%$ and without addition of SrF in total diet) and sex of the animal as block was applied. The feed as total mixed ration contained crude protein (CP) $17 \%$, total digestible nutrien (TDN) minimum 69\%, Net energy for maintenance $1.70 \mathrm{Mcal} / \mathrm{kg}$ and Net energy for gain $1.03 \mathrm{Mcal} / \mathrm{kg}$. It was fed $3 \%$ of body weight of the animals for 14 weeks included 2 weeks of adaptation period. Feces collection for measuring digestibility of feed was conducted at the end of experiment. Average daily gain (ADG) of calves received SrF was higher than without $\mathrm{SrF}$ (896.9 vs $853.7 \mathrm{~g}$ /day) while ADG received CaFA was lower than without CaFA (860.6 vs 890 $\mathrm{g} /$ day) but both effects were not significantly different $(\mathrm{P}>0.05)$. DM intake due to SrF treatment tended to be higher than control treatment (4.4 vs $4.3 \mathrm{~kg} /$ day). DM digestibility was not different among treatments. In conclusion, calves received supplementation of $0.3 \% \mathrm{SrF}$ fruit in the diet had similar average daily gain with those given unsupplemented diet but had reduced diarrhea cases. The use of Ca palm oil fatty acid as a dense energy source at $2.5 \%$ in the diet did not show any negative effect on calves performance.
\end{abstract}

Key Words: Sapindus rarak, Saponin, Calcium- Fatty Acid, Dairy Calves 


\section{INTRODUCTION}

Weaned calves require protein and energy to grow, however, the use of high energy in the form of fat will disturb the rumen function especially for young calves. The fat or fatty acid should be protected from degradation in the rumen as it causes negative effect to rumen function. The source of fatty acid that available abundantly in Indonesia is a byproduct from the cooking oil industry, called as palm oil fatty acid. Reaction palm oil fatty acid with calcium will produce calcium salt of palm oil fatty acid (CaFA) which will protect fatty acid from its degradation in the rumen and will not disturb the cellulolytic bacteria in the rumen, hence, does not negatively affect the rumen. The use of CaFA for dairy cow for early lactating period is very beneficial as it increased milk production (Reis et al. 2012; Rabiee et al. 2012). However, the information on the use of CaFA for calves as an energy source was only a few. It was reported an increase in weight gain for calves receiving diets containing $20 \%$ vs $10 \%$ (of DM) of a protected lipid source. Supplementation with $2.5 \%$ protected fat in calves feed increased feed conversion ratio, dry matter and fat digestibility of feed with low digestible protein content in the feed. Protein digestibility increased due to inclusion of protected fat in the diet (Cruywagen et al. 2003).

Sapindus rarak fruits $(\mathrm{SrF})$ contain high level of saponin and several experiments showed that $\mathrm{SrF}$ fruit reduced protozoa population in the rumen (Wina 2005; Wina 2012). Sapindus rarak fruit has been proven to destroy oocytes of Eimeria tenella in vitro (Pasaribu et al. 2014). Saponin has been reported to show antimicrobial or antifungal activity (Hassan et al. 2010; Saha et al. 2010). Weaned calves sometimes suffer from diarrhea. Therefore, the use of $\mathrm{SrF}$ fruit to calves may improve the performance of calves and prevent the occurrence of diarrhea on calves.

The aim of this experiment is to evaluate the supplementation of $\mathrm{SrF}$ fruit and CaFA in the diet to improve the growth performance of dairy calves.

\section{MATERIALS AND METHODS}

The experiment was done at the research station of Indonesian Research Institute for Animal Production. Thirty two newly weaned calves of Indonesian Holstein (4 months old) were placed in individual cement floor stall. They were divided randomly into 4 treatments. Each treatment consisted of 4 males and 4 females of calves. The experiment was conducted in factorial block design $2 \times 2$ with sex of the animal as block. First factor was Calcium palm oil fatty acid (CaFA) (with the level of $2.5 \% \mathrm{CaFa}$ of ration and without addition of CaFA and the second factor was S.rarak (SrF) fruit powder (with $0.3 \% \mathrm{SrF}$ of ration and without addition of $\mathrm{SrF}$ ) The treatments were: P1) Control feed (without SrF, without CaFA), P2) Feed with SrF, without CaFA, P3) Feed without SrF, with CaFA, P4) Feed with SrF, with CaFA. The total mixed ration contained CP 17\%, Net energy for maintenance $1.70 \mathrm{Mcal} / \mathrm{kg}$, Net energy for gain $1.03 \mathrm{Mcal} / \mathrm{kg}$. It consisted of elephant grass, ground corn, coconut meal, palm kernel meal, rice bran, soybean meal, molasses, limestone, salt, vitamin and mineral mix (Table 1). The feeding trial was conducted for 14 weeks including 2 weeks of adaptation period. The feed was fed twice a day at the level of $3 \%$ of body weight. Body weight was recorded every two weeks. Digestibility trial was conducted at the end of feeding trial where faeces were collected. The feed, feed residue and faeces were dried in the oven at $60^{\circ} \mathrm{C}$ for 3 days and milled after dried. The samples were analyzed for ash, crude protein, NDF, ADF, gross energy contents. The rumen liquor was taken from each animal and measured its $\mathrm{pH}$, ammonia, total bacteria and protozoa population.

\section{RESULTS AND DISCUSSION}

Addition of Calcium fatty acid (CaFA) in the diet resulted in similar intakes of $\mathrm{DM}, \mathrm{OM}, \mathrm{CP}, \mathrm{NDF}, \mathrm{ADF}$, Energy among treatments (Table 2). DM intake was significantly higher as S.rarak powder ( $\mathrm{SrF}$ ) was added into the diet compared to control (4.45 vs $4.29 \mathrm{~kg} /$ day). Crude protein intake tended to be higher due to $\mathrm{SrF}$ addition. There was no interaction effect of CaFA and $\mathrm{SrF}$ on intakes. There was no significant effect of CaFA on any digestibility (Table 2). SrF tended to decrease $\mathrm{NDF}$ and energy digestibility and $\mathrm{SrF}$ caused a significant decrease of ADF digestibility. There was no interaction effect of CaFA and SrF on digestibility.

Rumen condition had some changes in term of $\mathrm{pH}$ that increased significantly due to addition of SrF (Table 3 ). SrF tended to reduce total protozoa while it did not affect the total bacteria. CaFA did not give any significant effect on $\mathrm{pH}$, ammonia production and also did not change total bacteria or total protozoa in the rumen. There was no interaction effect of CaFA and $\mathrm{SrF}$ on rumen condition and microbes population.

Table 4 presents the average daily gain (ADG) and FCR of calves received SrF or CaFA for 12 weeks. ADG of calves receiving $\mathrm{CaFA}$ was lower than that without CaFA (860.6 vs $890 \mathrm{~g} /$ day) while ADG of calves receiving $\mathrm{SrF}$ was higher than that without $\mathrm{SrF}$ (896.9 vs $853.8 \mathrm{~g} /$ day) but both effects were not significantly different $(\mathrm{P}>0.05)$. ADG of male calves were higher than that of female (931 vs $819 \mathrm{~g} /$ day), however, the difference between ADG of male and of female calves was not significant (Figure 1).

During the experiment, it was recorded that some animals got diarrhea although it was only mild diarrhea. The diarrhea occurred to 3, 1, 5 and 7 animals for for P1) Control (without $\mathrm{SrF}$ and $\mathrm{CaFA}$ ), P2) with $\mathrm{SrF}$ without CaFA, P3) without SrF, with CaFA, P4) with $\mathrm{SrF}$ and CaFA treatments, respectively. 
Table 1. Diet composition and its calculated nutrient

\begin{tabular}{|c|c|c|c|c|}
\hline Ingredient $(\%)$ & $\begin{array}{c}\mathrm{P} 1 \\
\text { without } \mathrm{CaFA} \text {, } \\
\text { without } \mathrm{SrF}\end{array}$ & $\begin{array}{c}\text { P2 } \\
\text { without } \mathrm{CaFA} \text {, } \\
\text { with } \mathrm{SrF}\end{array}$ & $\begin{array}{c}\text { P3 } \\
\text { with } \mathrm{CaFA}, \\
\text { without } \mathrm{SrF}\end{array}$ & $\begin{array}{c}\text { P4 } \\
\text { With CaFA, } \\
\text { with SrF }\end{array}$ \\
\hline Elephant grass (DM) & 50 & 50 & 50 & 50 \\
\hline Corn grain (ground) & 12.9 & 12.9 & 9.1 & 9.1 \\
\hline Rice bran & 12.7 & 12.7 & 13.8 & 13.9 \\
\hline Copra meal & 12.5 & 12.5 & 12.5 & 12.5 \\
\hline Palm kernel meal & 2.8 & 2.8 & 2.8 & 2.8 \\
\hline Molasses & 2.5 & 2.5 & 2.5 & 2.4 \\
\hline Soybean meal & 5.2 & 5.2 & 5.7 & 5.7 \\
\hline Lime stone & 1 & 1 & 0.7 & 0.7 \\
\hline Salt & 0.3 & 0.3 & 0.3 & 0.3 \\
\hline Ruminant premix & 0.1 & 0.1 & 0.1 & 0.1 \\
\hline Ca-fatty acid (CaFA) & 0 & 0 & 2.5 & 2.5 \\
\hline TOTAL & 100.0 & 100.0 & 100.0 & 100.0 \\
\hline Sapindus rarak powder $(\mathrm{SrF})$ & 0 & 0.3 & 0 & 0.3 \\
\hline \multicolumn{5}{|l|}{ Calculated nutrient } \\
\hline Crude Protein $(\%)$ & 17 & 17 & 17 & 17 \\
\hline $\mathrm{TDN} \min (\%)$ & 69 & 69 & 69 & 69 \\
\hline Net energy for maintenance (Mcal/kg) & 1.70 & 1.70 & 1.70 & 1.70 \\
\hline Net energy for gain (Mcal/kg) & 1.03 & 1.03 & 1.03 & 1.03 \\
\hline $\mathrm{Ca} \min (\%)$ & 0.52 & 0.52 & 0.52 & 0.52 \\
\hline $\mathrm{P} \min (\%)$ & 0.31 & 0.31 & 0.31 & 0.31 \\
\hline
\end{tabular}

\section{DISCUSSION}

Weaned calves have usually problem in consuming new feed. It was also reported that the addition of Calcium fatty acid to the young calves depressed feed intake (Cruywagen et al. 2003) because calcium fatty acid might causea palatability problem. However, inclusion of $2.5 \%$ of $\mathrm{CaFA}$ in this experiment did not cause any negative effect on palatability. The calves did not show any rejection to any of feed containing CaFA. Surprisingly, SrF (Sapindus rarak fruit) increased DM intake significantly. This result was in agreement with the report that Sapindus Saponaria which increased OM intake of feed in sheep (Abreu et al. 2004). Sapindus rarak fruit contains high saponin level but saponin did not reduce intake, instead it increased intake. It was reported that addition of $3 \mathrm{~g}$ tea saponin/day in goat diet increased DM intake, although not significantly (Wang et al. 2012). Increased DM intake might be attributed to the increased efficiency of microbial protein synthesis (Uddin et al. 2015).
Digestibility of dry matter, organic matter and protein was not affected by the addition of CaFA or $\mathrm{SrF}$. Protection process of fatty acid by calcium prevented the negative effect of fatty acid to rumen microbes. It was reported that unprotected fat would cover the feed particle and prevent ruminal bacteria to degrade feed and unsaturated fatty acid in free form was toxic to some rumen microbes.

Fiber digestibility (NDF and ADF) significantly decreased by the addition of SrF. Saponin in $\mathrm{SrF}$ decreased fiber digestibility (NDF) in the rumen but not total tract fiber digestibility as reported by Wina (2005). $\mathrm{SrF}$ saponin reduced the activity of fibrolytic enzymes significantly and the activity had more positive correlation with the number of protozoa in the rumen of sheep (Wina et al. 2005). Protozoa exerts cellulase, hemicellulase, xylanase and glycoside hydrolase as reported by Williams \& Coleman (1988). In this experiment, total protozoa tended to decrease. Therefore, lower protozoa numbers might cause lower activity of fibrolytic enzymes to degrade fiber. 
Table 2. Effect of Calcium fatty acid (CaFA) and S.rarak fruit $(\mathrm{SrF})$ on daily intake of feed

\begin{tabular}{|c|c|c|c|c|c|c|c|}
\hline & \multicolumn{2}{|c|}{ CaFA factor } & \multicolumn{2}{|c|}{$\mathrm{SrF}$ factor } & \multirow[t]{2}{*}{ sem } & \multirow{2}{*}{$\frac{\mathrm{CaFA}}{\text { factor }}$} & \multirow{2}{*}{$\frac{\mathrm{SrF}}{\text { factor }}$} \\
\hline & without & with & without & with & & & \\
\hline \multicolumn{8}{|c|}{ Intake, g/head/day } \\
\hline DM & 4374 & 4372 & $4292^{\mathrm{a}}$ & $4454^{\mathrm{b}}$ & 49.15 & NS & $\mathrm{P}<0.03$ \\
\hline $\mathrm{OM}$ & 3942 & 3884 & 3844 & 3982 & 149.00 & NS & NS \\
\hline $\mathrm{CP}$ & 747 & 699 & 699 & 748 & 17.80 & NS & NS \\
\hline NDF & 1899 & 1854 & 1908 & 1845 & 80.25 & NS & NS \\
\hline $\mathrm{ADF}$ & 971 & 959 & 979 & 951 & 34.25 & NS & NS \\
\hline GE (Mcal) & 184 & 188 & 185 & 188 & 8.05 & NS & NS \\
\hline \multicolumn{8}{|l|}{ Digestibility (\%) } \\
\hline Dry matter & 72.17 & 71.68 & 73.08 & 70.76 & 1.16 & NS & NS \\
\hline Organic matter & 72.21 & 71.36 & 73.14 & 70.44 & 1.27 & NS & NS \\
\hline Crude protein & 72.24 & 69.83 & 70.75 & 71.32 & 1.62 & NS & NS \\
\hline NDF & 65.64 & 64.15 & 67.13 & 62.45 & 1.62 & NS & NS \\
\hline $\mathrm{ADF}$ & 55.75 & 53.29 & $57.65^{\mathrm{a}}$ & $51.39^{\mathrm{b}}$ & 2.03 & NS & $\mathrm{P}<0.04$ \\
\hline Gross Energy & 71.78 & 71.05 & 73.30 & 69.54 & 1.37 & NS & NS \\
\hline
\end{tabular}

Table 3. Effect of Calcium fatty acid (CaFA) and $S$. rarak fruit $(\mathrm{SrF})$ on rumen condition and microbial population of calves

\begin{tabular}{lccccccc}
\hline \hline & \multicolumn{2}{c}{ CaFA factor } & \multicolumn{2}{c}{ SrF factor } & sem & CaFA & SrF \\
\cline { 2 - 8 } & without & with & without & with & & factor & factor \\
\hline $\mathrm{pH}$ & 7.06 & 7.08 & $6.97^{\mathrm{a}}$ & $7.17^{\mathrm{b}}$ & 0.07 & $\mathrm{NS}$ & $\mathrm{P}<0.04$ \\
$\mathrm{NH} 3, \mathrm{mM}$ & 10.44 & 10.06 & 11.14 & 9.36 & 1.18 & $\mathrm{NS}$ & $\mathrm{NS}$ \\
Total bacteria $\left(10^{\wedge 9}\right)$ & 11.81 & 9.99 & 10.83 & 10.97 & 1.52 & $\mathrm{NS}$ & $\mathrm{NS}$ \\
Total protozoa $\left(10^{\wedge} 5\right)$ & 8.67 & 10.65 & 12.22 & 7.10 & 1.94 & $\mathrm{NS}$ & $\mathrm{NS}$ \\
\hline
\end{tabular}

Table 4. Effect of Calcium fatty acid (CaFA) and S.rarak fruit ( $\mathrm{SrF})$ on ADG and FCR of calves

\begin{tabular}{lccccccc}
\hline \hline & \multicolumn{2}{c}{ CaFA factor } & \multicolumn{2}{c}{ SrF factor } & sem & CaFA & SrF \\
\cline { 2 - 8 } & without & with & without & with & & factor & factor \\
\hline ADG g/day & 890.0 & 860.6 & 853.8 & 896.9 & 0.05 & NS & NS \\
FCR & 4.92 & 5.18 & 5.21 & 4.88 & 0.15 & NS & NS \\
\hline
\end{tabular}




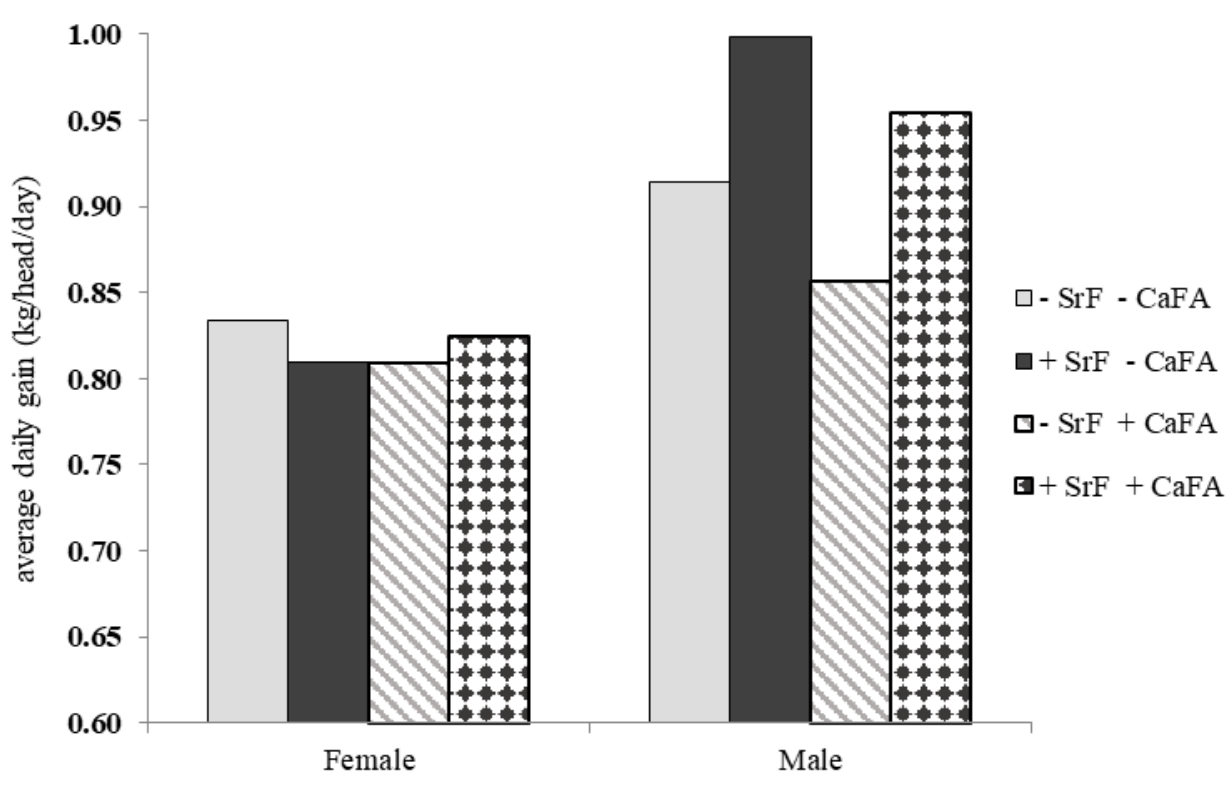

Figure 1. Average daily gain ( $\mathrm{kg} / \mathrm{head} / \mathrm{day})$ of female and male dairy calves supplemented without and with CaFA or SrF.

Several reports showed that ammonia production in the rumen was reported lower in the presence of saponin in the feed than control without saponin. Ammonia production in the rumen occurred from degradation of protein from either feed or proteolysis of bacterial protein when protozoa engulf ruminal bacteria or protozoal number. Contribution of total rumen nitrogen from protozoa was $10-40 \%$, and therefore, when protozoa number tended to reduce, the ammonia production in the rumen might be lower. In this experiment, since the protozoa number was also slightly reduced, the ammonia production in the rumen was not affected. It was reported that the efficiency of microbial protein synthesis was greater in forages containing saponin and tannins which reduce ruminal $\mathrm{N}$ degradability (Uddin et al. 2015), therefore it is expected that microbial protein entered abomasum and ileum was higher in the presence of $\mathrm{SrF}$, hence increase protein absorption and increase body weight gain. However, neither $\mathrm{CaFA}$ or $\mathrm{SrF}$ affected significantly the average daily gain (ADG) of weaned calves. Calcium fatty acid is a dense energy that can partly substitute corn when calcium fatty acid was included as part of the ingredients and formulated in the diet. In this experiment, $2.5 \% \mathrm{CaFA}$ in combination with rice bran substituted $29 \%$ of corn and produced similar average daily gain with diet without CaFA. There is an opportunity to substitute partly corn during the availability of corn is limited or during off season of corn.

The difference ADG between $\mathrm{SrF}$ and non-SrF fed calves was only $43 \mathrm{~g} /$ day (5\%) was too small compared to the high variation of ADG obtained by individual calf (26\%). The use of $\mathrm{SrF}$ at the level of $0.3 \%$ might be too low to give any significant effect on ADG. In sheep experiment, $\mathrm{SrF}$ was used at the level of $0.7 \%$ and significantly increased ADG of male sheep (Thalib et al. 2010; Wina 2005). In this experiment, although it was not significantly different, ADG of male calves were higher $(112 \mathrm{~g})$ than that of female. It was in agreement as reported in sheep when fed $40 \mathrm{mg} / \mathrm{kg}$ of Quillaja saponin, the male goat had higher daily gain than female goat. This experiment showed that the male calves had faster growth rate than female calves and they were very potential as meat type animal.

In this experiment, $\mathrm{SrF}$ reduced diarrhea problem in young animal. It is the first report on the effectiveness of $\mathrm{SrF}$ reduced diarrhea case in vivo. It was reported previously that Yucca saponin reduced the incidence of coccidiosis on calves when they were infected with Eimeria (Rambozzi et al. 2011).

Saponin in SrF effectively reduced protozoa population in the rumen and also reduced the growth of E.coli in newly weaned calves. Feeding of $\mathrm{SrF}$ to weaned calves should be taken carefully since their rumen has not developed well and saponin in $\mathrm{SrF}$ may depress the growth and activity of ruminal microbes.

\section{CONCLUSION}

The addition of Calcium palm fatty acid (CaFA) and Sapindus rarak fruit $(\mathrm{SrF})$ at the level of $2.5 \%$ and $0.3 \%$, respectively gave similar average daily gain with dairy calves fed without CaFA or SrF. Addition of Sapindus rarak fruit reduced diarrhea cases on calves. 


\section{REFERENCES}

Abreu A, Carulla JE, Lascano CE, Díaz TE, Kreuzer M, Hess HD. 2004. Effects of Sapindussaponaria fruits on ruminal fermentation and duodenal nitrogen flow of sheep fed a tropical grass diet with and without legume. J Anim Sci. 82:1392-1400.

Cruywagen CW, Lategan EL, Hoffman LC. 2003. The effect of rumen inert fat supplementation and protein degradability in starter and finishing diets on veal calf performance. South Afr J Anim Sci. 33:257-265.

Hassan SM, Haq AU, Byrd JA, Berhow MA, Cartwright AL, Bailey CA. 2010. Haemolytic and antimicrobial activities of saponin-rich extracts from guar meal. Food Chem. 119:600-605.

Pasaribu T, Wina E, Sumiati, Setiyono A, Astuti DA. 2014. Pengaruh tepung Sapindus rarak sebagai pakan aditif terhadap performa dan profil lipida ayam broiler yang diinfeksi Eimeria tenella. JITV. 19:263-271.

Rabiee R, Breinhild K, Scott W, Golder HM , Block E, Lean IJ. 2012. Effect of fat additions to diets of dairy cattle on milk production and components: A meta-analysis and meta-regression. J Dairy Sci. 95:3225-3247.

Rambozzi L, Min ARM, Menzano A. 2011. In vivo anticoccidial activity of Yucca schidigera saponins in naturally infected Calves. J Anim Vet Adv. 10:391-394.

Reis MM, Cooke RF, Ranches J, Vasconcelos JL. 2012. Effects of calcium salts of poly unsaturated fatty acids on productive and reproductive parameters of lactating Holstein cows. J Dairy Sci. 95:7039-7050.
Saha S, Walia S, Kumar J, Parmar BS. 2010. Structurebiological activity relationships in triterpenic saponins: The relative activity of protobassic acid and its derivatives against plant pathogenic fungi. Pest Manage Sci. 66:825-831.

Thalib A, Widiawati Y, Haryanto B. 2010. Utilization of complete rumen modifier on sheep fed high fibrous forages. JITV. 15:97-104.

Uddin MJ, Khanndaker ZH, Khan MJ, Khan MMH. 2015. Dynamics of microbial protein synthesis in the rumen A Review. Ann Vet Anim Sci. 2:116-131.

Wang JK, Ye JA, Liu JX. 2012. Effects of tea saponins on rumen microbiota, rumen fermentation, methane production and growth performance: a review. Trop Anim Health Prod. 44:697-706.

Williams AG, Coleman GS. 1988. The rumen protozoa. In: Hobson PN, editor. The Rumen Microbial Ecosystem. London and New York: Elsevier Applied Science. p. $77-128$.

Wina E. 2012. Saponins: Effect on rumen microbial ecosystem and metabolism in the rumen. In: Patra AK, editor. Dietary Phytochemicals and Microbes. Dordrecht (Germany): Springer. p. 311-350.

Wina E. 2005. The utilization of Sapindus rarak DC. saponins to improve ruminant production through rumen manipulation (Thesis). [Hohenheim (Germany)]: University of Hohenheim.

Wina E, Muetzel S, Becker K. 2005. The dynamics of major fibrolytic microbes and enzyme activity in the rumen in response to short- and long-term feeding of Sapindus rarak saponins. J Appl Microbiol. 100:114-122. 